\title{
Laminating the mammalian cortex during development: cell polarity protein function and Hippo signaling
}

\author{
Khadar Abdi ${ }^{1}$ and Chay T. Kuo ${ }^{1,2,3,4,5}$ \\ ${ }^{1}$ Department of Cell Biology, ${ }^{2}$ Department of Neurobiology, ${ }^{3}$ Preston Robert Tisch Brain Tumor Center, ${ }^{4}$ Brumley Neonatal/ \\ Perinatal Research Institute, ${ }^{5}$ Institute for Brain Sciences, Duke University School of Medicine, Durham, North \\ Carolina 27710, USA
}

\begin{abstract}
During mammalian brain development, radial glial progenitors balance between proliferation and differentiation to generate the laminated cortical layers in a temporally precise fashion. Defects in the individual steps going into this complex organogenesis can result in cortical malformations and human nervous system disorders. In this issue of Genes \& Development, Liu and colleagues (pp. 763-780) present experimental evidence that an evolutionarily conserved cellular polarity gene, Pard3 (partitioning-defective 3), controls the balance of radial glial proliferation and differentiation through interaction with the Hippo signal transduction pathway. Conditional deletion of Pard 3 in the developing rodent cortex resulted in striking subcortical band heterotopia, reminiscent of a severe form of human cortical malformation.
\end{abstract}

Cortical malformations are a form of central nervous system (CNS) disorder that has given us fundamental insights into mammalian brain development. These genetic diseases are grouped into three major categories including malformations caused by aberrant processes in (1) neuronal/glial proliferation or apoptosis, (2) neuronal migration, and (3) post-migrational development (Barkovich et al. 2012). Those cortical malformations arising from cellular migration defects are further subdivided into heterotopia, lissencephaly, subcortical band heterotopia, and cobblestone malformations. The developmentally expressed Doublecortin $(D C X)$ gene was first identified as a commonly mutated gene in subcortical band heterotopia patients, a class of cortical malformations associated with neuronal migration defects (Ross and Walsh 2001). Depending on the type and disease severity, patient symptoms accompanying cortical malformations can range from developmental delays to motor deficits to intellectual disability to epilepsy. In this issue

[Keywords: Hippo signaling; Notch signaling; megalencephaly with heterotopia; neurogenesis; pard3]

Corresponding author: chay.kuo@duke.edu

Article is online at http://www.genesdev.org/cgi/doi/10.1101/gad.316711. 118 . of Genes \& Development, Liu et al. (2018) describe a novel mutant mouse line with a conditional deletion of Pard3 (partitioning-defective 3) that develops megalencephaly with a giant ribbon-like subcortical band heterotopia. Intriguingly, this phenotype was induced via a combination of abnormal radial glial progenitor (RGP) proliferation and untimely neuronal differentiation instead of primarily through defective neuronal migration. The Par polarity gene family consists of seven members in its core group: three kinases (aPKC, Par-1, and Par-4), two scaffolding proteins (Par-3 and Par-6), one RING finger protein (Par-2), and a member of the 14-3-3 family of proteins (Par-5) (Goldstein and Macara 2007). Originally identified in a Caenorhabditis elegans genetic screen for asymmetric division mutants, this protein family establishes cellular polarity in diverse tissue types and is evolutionarily conserved (Kemphues et al. 1988). In epithelia, Pard3 is localized to tight junctions in complex with Pard6g (Pard6 $\gamma$; also known as Par-6) and Prkci (protein kinase $\mathrm{Cl}_{\text {; }}$ also known as aPKC), forming the boundaries between apical and basolateral domains. During mammalian cortical neurogenesis, RGPs retain both tight and adherens junctions to establish apical-basal polarity that is essential for their symmetric and asymmetric divisions during proliferation. While Pard3 function has been examined previously during CNS development (Bultje et al. 2009), it has not been genetically deleted from the rodent brain in vivo.

Using an Emx1-cre driver (targeting the cortex) to conditionally delete Pard 3 from embryonic RGPs, the investigators reported striking subcortical band heterotopia in the cerebral hemispheres. Temporal analyses of the mutant phenotypes showed that Pard3 plays potentially different roles during cortical lamination at two distinct developmental stages. During the early stages of RGP proliferation (embryonic days 13-15.5 [E13-E15.5]), Pard3 conditional mutants displayed increased symmetrical divisions,

(C) 2018 Abdi and Kuo This article is distributed exclusively by Cold Spring Harbor Laboratory Press for the first six months after the full-issue publication date (see http://genesdev.cshlp.org/site/misc/terms.xhtml). After six months, it is available under a Creative Commons License (Attribution-NonCommercial 4.0 International), as described at http://creativecommons.org/licenses/by-nc/4.0/. 
leading to aberrant and excess production of RGPs located outside the ventricular zone. This resulted in a concomitant reduction in the numbers of early-born $\mathrm{SABT}^{+}$ deep-layer neurons. Paradoxically, by E15.5-E17, Pard3 conditional mutants showed an increase in $\mathrm{SABT}^{+}$neurons just below the cortical plate as well as increased symmetrical differentiation of RGPs. The investigators attributed these seemingly divergent phenotypic outcomes following Pard3 deletion to varying levels of Notch activity between early and late cortical neurogenesis, consistent with an earlier observation from the same group showing Pard3's involvement in Notch signaling (Bultje et al. 2009).

Delving deeper into the underlying molecular mechanisms, the investigators reasoned that the subcortical band heterotopia phenotype seen may be analogous to dysregulations in organ size control. The Hippo pathway is an evolutionarily conserved cellular signaling mechanism critical for regulating the physical size of multiple organ systems (Yu and Guan 2013). In a tour de force set of genetic experiments, Liu et al. (2018) conditionally removed Yes-associated protein (YAP) and transcriptional coactivator with PDZ-binding motif (TAZ), two Hippo pathway downstream effectors that remarkably were able to rescue the megalencephaly and ribbon-like heterotopia phenotypes seen in Pard3 mutant animals. Growth factors, mechanical stimuli, polarity proteins, and morphogens intersect the Hippo pathway to control stem cell/progenitor cell proliferation, maintenance, and apoptosis (Yu and Guan 2013). A previous study of YAP during cortical development showed that its deletion resulted in hydrocephalus but without obvious defects in cortical lamination (Park et al. 2016). Similarly, the double knockout of YAP and TAZ here showed a hydrocephalic phenotype with no associated defects in cortical lamination. Although the rescued animals appeared to have reduced numbers of $\mathrm{CUX}^{+}$cortical neurons, given that Pard3 has additional functions in progenitor cell cycle spindle orientation and progeny migration, the extent of the in vivo phenotypic rescue via YAP/TAZ deletions remains striking. The Hippo pathway and YAP/TAZ have been linked recently to cell migration (Sakabe et al. 2017), providing a potential molecular basis for the in vivo rescue of the Pard3 mutation phenotype. The investigators' observation that Hippo signaling was abnormally low during the early phase of cortical neurogenesis in Pard3 conditional mutants but became induced during the late phase is also consistent with the mutant phenotypes.

This elegant and mechanistic study connects the evolutionarily conserved Pard3 gene to megalencephaly and ribbon-like subcortical heterotopia. Human PARD3 mutations have thus far been implicated in neural tube defects (Chen et al. 2017), but this study provides a strong rationale for further examination of its linkage to brain developmental defects. In addition to analyzing heritable germline genetic mutations in cortical malformations, screens focusing on somatic mutations arising during de- velopment have been fruitful. Extracting DNA from blood leukocytes and using next-generation sequencing to look at specific genes known to cause cortical malformations, DCX and Lissencephaly 1 (LIS1) somatic mutations have been identified in individuals with double-cortex syndrome and periventricular nodular heterotopia, respectively (Jamuar et al. 2014). A similar screening approach for potential genetic mutations in $P A R D 3$, related cellular polarity genes, and components of the Hippo signaling pathway may uncover novel human defects that give rise to cortical malformations during development.

\section{Acknowledgments}

This work was supported by National Institutes of Health grants R01MH105416, R01NS078192, and R01NS096096 and the March of Dimes.

\section{References}

Barkovich AJ, Guerrini R, Kuzniecky RI, Jackson GD, Dobyns WB. 2012. A developmental and genetic classification for malformations of cortical development: update 2012. Brain 135: 1348-1369.

Bultje RS, Castaneda-Castellanos DR, Jan LY, Jan YN, Kriegstein AR, Shi SH. 2009. Mammalian Par3 regulates progenitor cell asymmetric division via notch signaling in the developing neocortex. Neuron 63: 189-202.

Chen X, An Y, Gao Y, Guo L, Rui L, Xie H, Sun M, Lam Hung S, Sheng X, Zou J, et al. 2017. Rare deleterious PARD3 variants in the aPKC-binding region are implicated in the pathogenesis of human cranial neural tube defects via disrupting apical tight junction formation. Hum Mutat 38: 378-389.

Goldstein B, Macara IG. 2007. The PAR proteins: fundamental players in animal cell polarization. Dev Cell 13: 609-622.

Jamuar SS, Lam AT, Kircher M, D'Gama AM, Wang J, Barry BJ, Zhang X, Hill RS, Partlow JN, Rozzo A, et al. 2014. Somatic mutations in cerebral cortical malformations. N Engl J Med 371: 733-743.

Kemphues KJ, Priess JR, Morton DG, Cheng NS. 1988. Identification of genes required for cytoplasmic localization in early $C$. elegans embryos. Cell 52: 311-320.

Liu WA, Chen S, Li Z, Lee CH, Mirzaa G, Dobyns WB, Ross ME, Zhang J, Shi S-H. 2018. PARD3 dysfunction in conjunction with dynamic HIPPO signaling drives cortical enlargement with massive heterotopia. Genes Dev (this issue). doi: 10.1101/gad.313171.118.

Park R, Moon UY, Park JY, Hughes LJ, Johnson RL, Cho SH, Kim S. 2016. Yap is required for ependymal integrity and is suppressed in LPA-induced hydrocephalus. Nat Commun 7: 10329.

Ross ME, Walsh CA. 2001. Human brain malformations and their lessons for neuronal migration. Annu Rev Neurosci 24: 1041-1070.

Sakabe M, Fan J, Odaka Y, Liu N, Hassan A, Duan X, Stump P, Byerly L, Donaldson M, Hao J, et al. 2017. YAP/TAZCDC42 signaling regulates vascular tip cell migration. Proc Natl Acad Sci 114: 10918-10923.

Yu FX, Guan KL. 2013. The Hippo pathway: regulators and regulations. Genes Dev 27: 355-371. 


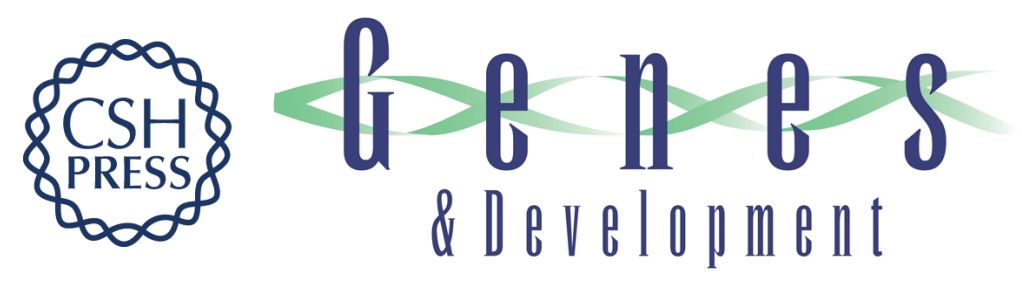

\section{Laminating the mammalian cortex during development: cell polarity protein function and Hippo signaling}

Khadar Abdi and Chay T. Kuo

Genes Dev. 2018, 32:

Access the most recent version at doi:10.1101/gad.316711.118

Related Content PARD3 dysfunction in conjunction with dynamic HIPPO signaling drives cortical enlargement with massive heterotopia

Wenying Angela Liu, She Chen, Zhizhong Li, et al.

Genes Dev. June, 2018 32: 763-780

References This article cites 11 articles, 3 of which can be accessed free at:

http://genesdev.cshlp.org/content/32/11-12/740.full.html\#ref-list-1

Articles cited in:

http://genesdev.cshlp.org/content/32/11-12/740.full.html\#related-urls

Creative This article is distributed exclusively by Cold Spring Harbor Laboratory Press for the first

Commons

License

six months after the full-issue publication date (see

http://genesdev.cshlp.org/site/misc/terms.xhtml). After six months, it is available under a Creative Commons License (Attribution-NonCommercial 4.0 International), as described at http://creativecommons.org/licenses/by-nc/4.0/.

Email Alerting Receive free email alerts when new articles cite this article - sign up in the box at the top

Service right corner of the article or click here.

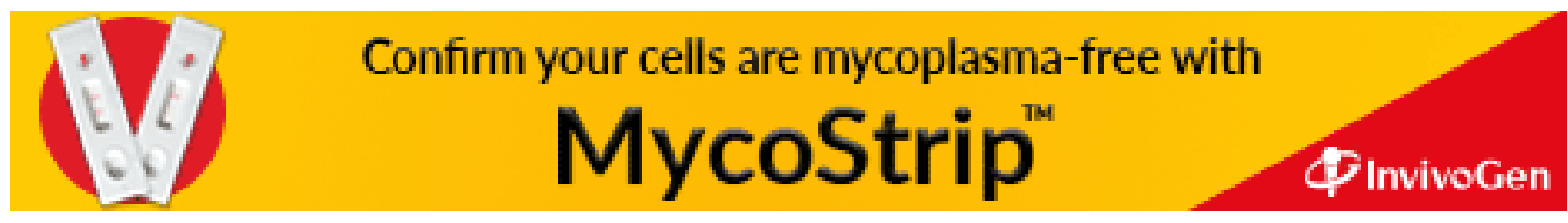

